\title{
Measuring Transit Accessibility Potential: A Corridor Case Study
}

\author{
Rajesh J Pandya \\ Town Planner, Town Planning Department, Surat Municipal Corporation, Gujarat, India
}

\begin{abstract}
Buses are the most widely used and essential component of a public transit system and the selection of a bus route are very important as it affects the overall performance of the system and its efficiency. Moreover the bus routes and bus stop locations are very important criteria for selection of this mode of transport by commuters. Bus stops attain their importance to the transit service as they are the main points of contact between the passenger and the bus. Considering spatial attributes, both the location and the spacing of bus routes and bus stops significantly affect transit service performance and passenger satisfaction, as they influence travel time in addition to their role in ensuring reasonable accessibility. Knowing that every transit trip begins and ends with pedestrian travel, access to a bus stop is considered a critical factor for assessing the accessibility of the stop location. In this paper, on the basis of the actual population surrounding the stop, the potential of a particular bus route / corridor is estimated for a particular corridor so as to assess a bus route / corridor on a more spatial basis. This potential measures the efficiency of a bus route / corridor through the surrounding road network, which can be used to compare the performance / efficiency of two or more routes / corridors in a system and also o ways to improve the performance of a particular route by increasing number of bus stops or changing their locations.
\end{abstract}

\section{INTRODUCTION}

Public transportation is a key component of a sustainable transportation system that improves mobility without placing economic and environmental burden of increased auto ownership on the travelling population. Due to lack of public transport facilities, significant growth in personalized vehicle population and considerable reduction in city bus transportation is observed.

Most of the metropolitan cities lack proper accessibility to public transport. Transport and land use planning have a significant role in promoting accessibility, and at the same time accessibility is becoming increasingly important in making sound and sustainable land use and transport decisions. Therefore, $t$ is important to develop models that are able to measure accessibility to public transport networks.

\section{ACCESSIBILITY CONCEPT}

Accessibility is a commonly used concept in transport planning, urban planning and in geography. Accessibility is often defined as the ease of travel between two locations. The Oxford Advanced learner's Dictionary (2000) defines 'accessible' as "that can be reached, entered, used, seen, etc." Accessibility can be defined as the effort or ease with which activities can be reached using the available transportation system. Accessibility has been regarded a property of places showing how easily they can be accessed from other places, as well as a property of people indicting how easily they can reach a set of potential destinations.

\subsection{ACCESSIBILITY MEASURES: CERTAIN APPROACHES}

Baradaran \& Ramjerdi (2001) classified the approaches for measuring accessibility into:

Travel cost approach which reflects the "spatial separation" characteristics of a transportations net work, i.e., distance, time, generalize cost, etc.

Constraints based approach which reflects the number of activities (or opportunities) that can be reached from an origin point within a certain time limit.

Gravity approach derived from the gravity model formula, which reflects both the attractiveness of zones and the quality of the transportation system that connects them.

Utility based approach developed on basis of disaggregate / behavioral approach originally proposed by Ben akiva and Lerman(1978) and therefore they reflect, in addition to the characteristics of the transportation system, the utility that different alternatives of services or facilities have to the users;

Composite approach developed by combining the space time and utility based models and it assumes uniform travel speed;

\subsection{Transit ACCESSIBILITY}

Many factors contribute to transit accessibility, including reasonable proximity from the origin and the destination to the service, safe, pleasant and comfortable walking pathways to transit facilities, and acceptable parking facilities for cars or bicycles, etc. In public transit planning, access to the service and accessibility 
provided by the service are two very important issues (Murray et al 1998). Access is the ease with which people can reach the transit stop. Accessibility is the suitability of the transit system in helping people get to their destinations in a reasonable amount of time as shown in Fig 1.

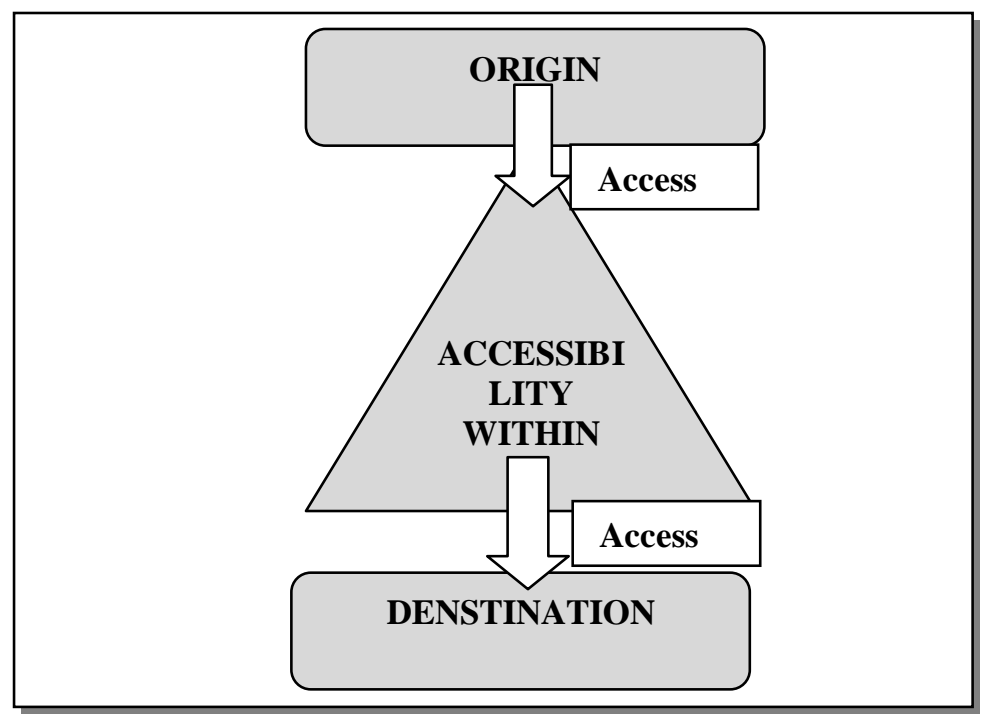

(Source: Murray et al 1998)

Fig 1 Public Transport System Access

Of the many factors, walking distance to transit facilities is recognized as an important determinant of transit use. A quarter mile approximately $400 \mathrm{~m}$. is the commonly accepted distance for people willing to walk to use transit (Demetsky and Lin 1982) Cerero (1994) found that proximity to a rail station was a much stronger determinant of transit use than land use mix or quality of the walking environment. Levinson and Brown West (1984) indicated in their study that transit use sharply drop after the first 0.06 mile, and diminish beyond 0.36 mile. Zhao, Li, and Chow (2002) found that transit use deteriorates exponentially with walking distance to transit stops. A decay function was developed to reflect the deteriorating trend in transit use with respect to walk distance. So, increasing suitable access to transit systems is seen as a means of attracting more people to the transit system.

\subsection{Measuring Transit ACCess}

GIS can be thought of as a system, digitally creates and "manipulates" spatial areas that may be jurisdictional, purpose or application oriented for which a specific GIS is developed. For measurement of accessibility GIS is very important tool. Traditionally, transit access is measured using the GIS buffer technique. In this method access is defined as a walking distance to a public transit stop, and then all the areas within the threshold distance of all stops are identified. People living in the areas identified as within the threshold distance are said to have suitable access. Generally the specified distance is quarter mile from bus stops. There are problems with this method. One is that it assumes Euclidean walking distance to a transit stop. When in reality the pathways are always longer, and must follow the actual street network. Another issue is that information on the exact residence or location of individuals is not available. The most precise geographic information which exists is census data reported at some aggregate scale.

\subsection{Location and Linkages}

\section{STUDY CORRIDOR}

Dumas road is one of the major roadway corridor for the city of Surat. It is located on the western part of the city. It starts from Athwa gate junction at the inner ring road and ends at the coastal villages of Dumas and Bhimpore. The population density is very high at the eastern part of the corridor where, important government establishment like Government Multi story Office Complex, Police Bhavan, Session and District Courts generate a very high volume of traffic. Moreover educational and commercial campuses, hospitals and commercial establishments also add to the heavy traffic flow.

A number of important traffic routes are linked with this corridor like inner ring road at Athwa junction; Ghod Dod road at Parle Point junction; City light road at Jani Farsan junction; Piplod / University Road at Kargil Chowk; Vesu Road near Big Bazar, Udhana Magdalla Road at Y junction and the 90 mts. outer ring road i.e. Sachin Magdalla National Highway. These major roads are very important linkages and increase the importance of Athwa Dumas Corridor. 


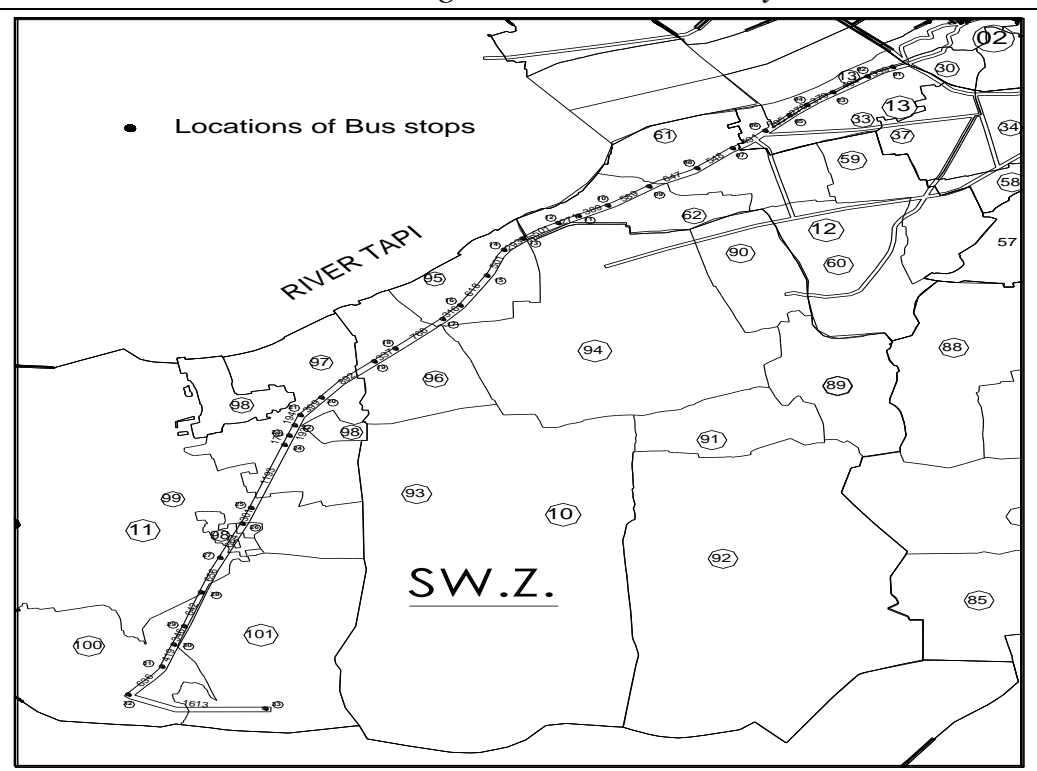

Fig 2 Athwa Dumas Corridor and Location of Bus Stops

\subsection{Demographic Profile}

This corridor of length $16.47 \mathrm{~km}$ is located the South West (Athwa) administrative zone of Surat City and in doing so it passes through nine different census ward out of which three wards are in the old city limits and six census wards fall within the areas newly annexed into municipal limits after 2006. The population and density of these words are shown in Table 1 and 2.At present there are 33 designated bus stops along the route.

Table 1 Census Wards of Old City Areas Through which Athwa Dumas Road passes

\begin{tabular}{|l|l|l|l|}
\hline Ward Nos. & $\begin{array}{l}\text { 33 } \\
\text { ( TP 5 Athwa - Umra) }\end{array}$ & $\begin{array}{l}61 \\
\text { (Umra) }\end{array}$ & $\begin{array}{l}62 \\
\text { (Piplod) }\end{array}$ \\
\hline Population & 30,585 & 54,046 & 17,588 \\
\hline Density & 17,991 & 11,852 & 9,160 \\
\hline
\end{tabular}

Table 2 Census Wards of New City Areas Through which Athwa Dumas Road passes

\begin{tabular}{|l|l|l|l|l|l|l|}
\hline Ward Nos. & $\begin{array}{l}95 \\
\text { (Rundh) }\end{array}$ & $\begin{array}{l}96 \\
\text { (Magdalla) }\end{array}$ & $\begin{array}{l}97 \\
\text { (Gavier) }\end{array}$ & $\begin{array}{l}99 \\
\text { (Dumas) }\end{array}$ & $\begin{array}{l}100 \\
\text { (Sultanabad) }\end{array}$ & $\begin{array}{l}101 \\
\text { (Bhimpor) }\end{array}$ \\
\hline Populations & 4355 & 6104 & 2585 & 7225 & 3659 & 7861 \\
\hline Density & 1192 & 2655 & 637 & 351 & 814 & 1230 \\
\hline
\end{tabular}

\subsection{Public Transit Accessibility Index (PTAI)}

\section{POTENTIAL OF CORRIDOR.}

It is required to bring the walking distance in certain modules for relative comparison so that one can consider the level of service status. In view of this Accessibility Index value with reference to walking distance accessibility may be defined as the increase of walking distance (in Kilometers).

Table 3 Public Transit ACCessibility Index

$\left.\begin{array}{|l|l|l|l|l|l|}\hline \text { Walking Distance (Meters) } & <250 & 350 * & 450 & 550 & >950 \\ \hline \text { PTAI (WD) } & 4 & 2.85 & 2.2 & 1.81 & 1.05 \\ \hline & \left.* \frac{1 \mathrm{x} 1000}{350}\right]=2.85\end{array}\right]$

Here the PTAI (WD) value of 250, 350, 450, and 950 are converted into index values of 4, 2.85, 2.22, 1.81 and 1.05 . Higher the index value better is the transit accessibility. 
4.2 Potential of a Bus Stop

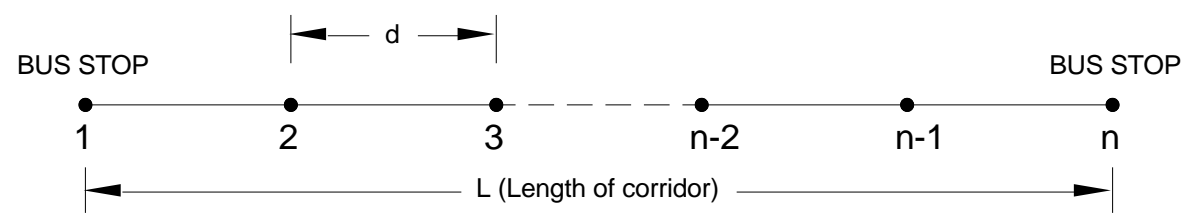

Figure 3 Schematic Diagram of Bus Route

Number of Bus Stop

Population of Zone

Area of Zone

Density of Zone Di $=\mathrm{i}(1$ to $n)$

$=$ Pi Persons

$=\mathrm{Zi}$ Square kilometer

$=\mathrm{Pi} / \mathrm{Zi}$ Person per square kilometer

$$
=\text { PTAI } \mathrm{w}
$$$$
=\pi \mathrm{w} 2
$$

$$
=\text { Di } \times \text { Aiw }
$$

$=$ Piw $x$ PTAI $\mathrm{w}$

Potential of Bus Stop for

walking distance $\mathrm{w}$ (i)

Gross Potential of Bus Stop for all three walking distance $=\Sigma$ Potential $\mathrm{w}$

Average Potential of Bus Stop

$=\frac{\Sigma \text { Gross Potential (i) }+\Sigma \text { GrossP }(\mathrm{i}+\mathrm{i})}{2 \mathrm{~d}}$

Overall Potential Index of route

$$
=\frac{\sum_{i=1}^{\sum} \text { Average Potential of Bus Stop }}{L^{\prime}}
$$

\subsection{Calculating the Potential}

found.

(1)First of all the density of population for the census ward within which the bus-stop is located is

Density $($ persons $/ \mathrm{km} 2)=\frac{(\text { population of Zone })}{\text { Area of Zone }} \quad \mathrm{Di}=\frac{\mathrm{Pi}}{\mathrm{Zi}}$

(2) For different walking distance (250 m, 350m, $450 \mathrm{~m})$

The Public Transit Accessibility Index (PTAI) is found.

\begin{tabular}{|l|l|l|l|}
\hline $\begin{array}{l}\text { Walking } \\
\text { Distance (w) }\end{array}$ & 250 & 350 & 450 \\
\hline PTAI (w) & 4.00 & 2.86 & 2.22 \\
\hline
\end{tabular}

(3) Population within the command area (walking distance) of bus-stop which has direct walking accessibility to bus stop is calculated and D (i) is found.

$$
\text { Population (iw) }=\text { Density Di } x \text { Aw }
$$

Potential of a bus stop (i) for a walking distance $\mathrm{w}$ is for $=\mathrm{P}$ iw $\mathrm{x}$ PTAI (w).

(4) Using different walking distances $250 \mathrm{~m}, 350 \mathrm{~m}$ and $450 \mathrm{~m}$ different potentials for all bus stops is found and the sum of all three potentials for a particular bus stop gives the gross potential of a bus stop (i) for all three walking distances. Using 6TPAI (i) and using gross potential of adjacent bus stops the average Potential of a bus stop is found.

(5) Sum total of all the Average potentials divided by number of stops gives the overall Public Transport Accessibility Index of the route per bus stop.

Overall Potential $=\quad \Sigma$ Average Potential

Total number of bus stops

If the sum is divided by the total length of the route (bus corridor ' $\mathrm{L}$ ') we get the overall Potential per running kilometer.

$\Sigma$ Average Potential of Bus Stop

Overall Potential $=$ $\mathrm{i}=1$

Length of the Route 'L' 
In the present case study the potential of the corridor is calculated w.r.t. 33 present / designated stops and also w.r.t length of the corridor (per km).the Potential w.r.t length can be utilized for comparison of performance / potential of different corridors or for some corridor for different time.

The potential w.r.t bus stands ( per stop) can be used for analysis of improvement of the bus route by increasing the number of bus stands and their locations.

\section{CONCLUSION}

Using the powerful GIS network analysis functions, indices can be developed to assist in the assessment of a bus stop locations, also the process can be used to find out the potential of the bus route as a whole or for different parts of it. The results can be utilized for improvement of the performance of the public transport system and can be used for further studies.

Accessibility and linkage with potential users of the bus stop and using information on population densities for different urban districts and transforming it in terms of persons per km; hence, an extra important attribute for the polyline layer can be added other than the travel distance or time. This can be viewed as a three dimensional coordinate where the third dimension represents the population. Moreover, the effect of time on the demand variability also can be introduced through the use of appropriate data in morning / evening peak periods or even on a seasonal basis.

Distribution of potential users within the circular buffer zone for example, by creating various circles radiating from the location of the bus stop with $50 \mathrm{~m}$ increments and locating the share of the total network length in $\mathrm{km}$ within each.

Study of accessibility thirst areas and analysing ways to meet this requirement so as to satisfy a demand and at the same time improve the potential of the transit system.

Analysis of important routes meeting, closing and making with the present Athwa Dumas corridor under study and the effect of changes, variations, improvement of the new additional roads.

Accessing the effect of feeder services though para transit modes or feeder routes to strengthen the existing bus route. Suggesting new bus stops after assessing the shortfall for present condition and additional requirement for projected population growth and development of the area.

\section{REFERENCES}

[1] AccessibilityGuidelineforBuildingandFacilitiescap:10TransportationFacilities,Availableashttp://www.accessboard.gov/adaag/html/a daag2.htm;

[2] Ammons, D.N.2001, Municipal Benchmarks: Assessing Local Performance and Establishing Community Standards, Second Edition. Sage,thousand Oaks,CA.

[3] Central Ohio Transit Authority, 1999, Planning and Development Guidelines for Public Transit.COTA,Columbus,OH.

[4] Christchurch, Bus Stop Location Policy, Available as http://www.ccc.govt.nz/policy/bus-2,asp;

[5] Mohamed A. Foda, "Using GIS for Measuring Transit Stop Accessibility Considering Actual Pedestrian Road Network.

\section{APPENDIX - I}

PTAI ( i ) FOR WALKING DISTANCE 250 METRE

\begin{tabular}{|c|c|c|c|c|c|c|c|}
\hline \multirow{2}{*}{$\begin{array}{l}\text { Bus } \\
\text { Stop }\end{array}$} & \multirow{2}{*}{ CensusWard } & \multirow{2}{*}{$\begin{array}{l}\text { Area } \\
\text { (Sq. } \\
\mathrm{Km})\end{array}$} & \multirow{2}{*}{$\begin{array}{l}\text { Pop. } \\
\text { at } 2011\end{array}$} & \multirow{2}{*}{$\begin{array}{l}\text { Density } \\
(\text { Persons } \\
\left.\text { per } \mathrm{Km}^{2}\right)\end{array}$} & \multicolumn{3}{|c|}{ For Walking Distance 250 Meter } \\
\hline & & & & & $\begin{array}{l}\text { PTAI }= \\
1 / 0.250\end{array}$ & $\begin{array}{l}\text { Pop. } 250= \\
\text { D x } 0.1964\end{array}$ & $\begin{array}{l}\text { P(i) } \quad x \\
\text { PTAI }\end{array}$ \\
\hline 1 & 33 & 1.7 & 30585 & 17991 & 4.00 & 3533.47 & 14133.87 \\
\hline 2 & 33 & 1.7 & 30585 & 17991 & 4.00 & 3533.47 & 14133.87 \\
\hline 3 & 33 & 1.7 & 30585 & 17991 & 4.00 & 3533.47 & 14133.87 \\
\hline 4 & 33 & 1.7 & 30585 & 17991 & 4.00 & 3533.47 & 14133.87 \\
\hline 5 & 33 & 1.7 & 30585 & 17991 & 4.00 & 3533.47 & 14133.87 \\
\hline 6 & 33 & 1.7 & 30585 & 17991 & 4.00 & 3533.47 & 14133.87 \\
\hline 7 & 61 & 4.56 & 54046 & 11852 & 4.00 & 2327.77 & 9311.08 \\
\hline 8 & 61 & 4.56 & 54046 & 11852 & 4.00 & 2327.77 & 9311.08 \\
\hline 9 & 62 & 1.92 & 17588 & 9160 & 4.00 & 1799.11 & 7196.42 \\
\hline 10 & 62 & 1.92 & 17588 & 9160 & 4.00 & 1799.11 & 7196.42 \\
\hline 11 & 62 & 1.92 & 17588 & 9160 & 4.00 & 1799.11 & 7196.42 \\
\hline
\end{tabular}


Measuring Transit Accessibility Potential: A Corridor Case Study

\begin{tabular}{|l|l|l|l|l|l|l|l|}
\hline 12 & 62 & 1.92 & 17588 & 9160 & 4.00 & 1799.11 & 7196.42 \\
\hline 13 & 62 & 1.92 & 17588 & 9160 & 4.00 & 1799.11 & 7196.42 \\
\hline 14 & 95 & 3.652 & 4355 & 1192 & 4.00 & 234.21 & 936.83 \\
\hline 15 & 95 & 3.652 & 4355 & 1192 & 4.00 & 234.21 & 936.83 \\
\hline 16 & 95 & 3.652 & 4355 & 1192 & 4.00 & 234.21 & 936.83 \\
\hline 17 & 95 & 3.652 & 4355 & 1192 & 4.00 & 234.21 & 936.83 \\
\hline 18 & 96 & 2.299 & 6104 & 2655 & 4.00 & 521.46 & 2085.82 \\
\hline 19 & 96 & 2.299 & 6104 & 2655 & 4.00 & 521.46 & 2085.82 \\
\hline 20 & 97 & 4.061 & 2585 & 637 & 4.00 & 125.02 & 500.07 \\
\hline 21 & 97 & 4.061 & 2585 & 637 & 4.00 & 125.02 & 500.07 \\
\hline 22 & 97 & 4.061 & 2585 & 637 & 4.00 & 125.02 & 500.07 \\
\hline 23 & 97 & 4.061 & 2585 & 637 & 4.00 & 125.02 & 500.07 \\
\hline 24 & 97 & 4.061 & 2585 & 637 & 4.00 & 125.02 & 500.07 \\
\hline 25 & 99 & 20.577 & 7225 & 351 & 4.00 & 68.96 & 275.84 \\
\hline 26 & 99 & 20.577 & 7225 & 351 & 4.00 & 68.96 & 275.84 \\
\hline 27 & 99 & 20.577 & 7225 & 351 & 4.00 & 68.96 & 275.84 \\
\hline 28 & 99 & 20.577 & 7225 & 351 & 4.00 & 68.96 & 275.84 \\
\hline 29 & 100 & 4.491 & 3659 & 815 & 4.00 & 160.02 & 640.06 \\
\hline 30 & 100 & 4.491 & 3659 & 815 & 4.00 & 160.02 & 640.06 \\
\hline 31 & 100 & 4.491 & 3659 & 815 & 4.00 & 160.02 & 640.06 \\
\hline 32 & 100 & 4.491 & 3659 & 815 & 4.00 & 160.02 & 640.06 \\
\hline 33 & 101 & 6.389 & 7861 & 1230 & 4.00 & 241.65 & 966.60 \\
\hline
\end{tabular}

APPENDIX - II

PTAI ( ii ) FOR WALKING DISTANCE 350 METRE

\begin{tabular}{|c|c|c|c|c|c|c|c|c|}
\hline \multirow{2}{*}{$\begin{array}{l}\text { Bus } \\
\text { Stop }\end{array}$} & \multirow[b]{2}{*}{$\begin{array}{l}\text { CensusWa } \\
\text { rd }\end{array}$} & \multirow{2}{*}{$\begin{array}{l}\text { Area } \\
\text { (Sq. } \\
\text { Km) }\end{array}$} & \multirow{2}{*}{$\begin{array}{l}\text { Pop. } \\
\text { at } 2011\end{array}$} & \multirow{2}{*}{$\begin{array}{l}\text { Density } \\
(\text { Persons } \\
\text { per } \mathrm{Km}^{2} \text { ) }\end{array}$} & \multicolumn{4}{|c|}{ For Walking Distance 350 Metre } \\
\hline & & & & & $\begin{array}{l}\text { PTAI = } \\
1 / 0.350\end{array}$ & $\begin{array}{l}\text { Pop. } 350= \\
D(i) \times 0.385\end{array}$ & $\begin{array}{l}\text { Pop. of } \\
350-250\end{array}$ & $\begin{array}{l}\text { P(i) } \quad \mathrm{x} \\
\text { PTAI }\end{array}$ \\
\hline 1 & 33 & 1.7 & 30585 & 17991 & 2.86 & 6926.60 & 3393.14 & 9694.67 \\
\hline 2 & 33 & 1.7 & 30585 & 17991 & 2.86 & 6926.60 & 3393.14 & 9694.67 \\
\hline 3 & 33 & 1.7 & 30585 & 17991 & 2.86 & 6926.60 & 3393.14 & 9694.67 \\
\hline 4 & 33 & 1.7 & 30585 & 17991 & 2.86 & 6926.60 & 3393.14 & 9694.67 \\
\hline 5 & 33 & \begin{tabular}{|l|}
1.7 \\
\end{tabular} & 30585 & 17991 & 2.86 & 6926.60 & 3393.14 & 9694.67 \\
\hline 6 & 33 & 1.7 & 30585 & 17991 & 2.86 & 6926.60 & 3393.14 & 9694.67 \\
\hline 7 & 61 & 4.56 & 54046 & 11852 & 2.86 & 4563.09 & 2235.32 & 6386.64 \\
\hline 8 & 61 & 4.56 & 54046 & 11852 & 2.86 & 4563.09 & 2235.32 & 6386.64 \\
\hline 9 & 62 & 1.92 & 17588 & 9160 & 2.86 & 3526.76 & 1727.65 & 4936.16 \\
\hline 10 & 62 & 1.92 & 17588 & 9160 & 2.86 & 3526.76 & 1727.65 & 4936.16 \\
\hline 11 & 62 & 1.92 & 17588 & 9160 & 2.86 & 3526.76 & 1727.65 & 4936.16 \\
\hline 12 & 62 & 1.92 & 17588 & 9160 & 2.86 & 3526.76 & 1727.65 & 4936.16 \\
\hline 13 & 62 & 1.92 & 17588 & 9160 & 2.86 & 3526.76 & 1727.65 & 4936.16 \\
\hline 14 & 95 & 3.652 & 4355 & 1192 & 2.86 & 459.11 & 224.90 & 642.59 \\
\hline 15 & 95 & 3.652 & 4355 & 1192 & 2.86 & 459.11 & 224.90 & 642.59 \\
\hline 16 & 95 & 3.652 & 4355 & 1192 & 2.86 & 459.11 & 224.90 & 642.59 \\
\hline 17 & 95 & 3.652 & 4355 & 1192 & 2.86 & 459.11 & 224.90 & 642.59 \\
\hline 18 & 96 & 2.299 & 6104 & 2655 & 2.86 & 1022.20 & 500.75 & 1430.70 \\
\hline 19 & 96 & 2.299 & 6104 & 2655 & 2.86 & 1022.20 & 500.75 & 1430.70 \\
\hline 20 & 97 & 4.061 & 2585 & 637 & 2.86 & 245.07 & 120.05 & 343.01 \\
\hline 21 & 97 & 4.061 & 2585 & 637 & 2.86 & 245.07 & 120.05 & 343.01 \\
\hline 22 & 97 & 4.061 & 2585 & 637 & 2.86 & 245.07 & 120.05 & 343.01 \\
\hline
\end{tabular}


Measuring Transit Accessibility Potential: A Corridor Case Study

\begin{tabular}{|l|l|l|l|l|l|l|l|l|}
\hline 23 & 97 & 4.061 & 2585 & 637 & 2.86 & 245.07 & 120.05 & 343.01 \\
\hline 24 & 97 & 4.061 & 2585 & 637 & 2.86 & 245.07 & 120.05 & 343.01 \\
\hline 25 & 99 & 20.577 & 7225 & 351 & 2.86 & 135.18 & 66.22 & 189.20 \\
\hline 26 & 99 & 20.577 & 7225 & 351 & 2.86 & 135.18 & 66.22 & 189.20 \\
\hline 27 & 99 & 20.577 & 7225 & 351 & 2.86 & 135.18 & 66.22 & 189.20 \\
\hline 28 & 99 & 20.577 & 7225 & 351 & 2.86 & 135.18 & 66.22 & 189.20 \\
\hline 29 & 100 & 4.491 & 3659 & 815 & 2.86 & 313.68 & 153.66 & 439.03 \\
\hline 30 & 100 & 4.491 & 3659 & 815 & 2.86 & 313.68 & 153.66 & 439.03 \\
\hline 31 & 100 & 4.491 & 3659 & 815 & 2.86 & 313.68 & 153.66 & 439.03 \\
\hline 32 & 100 & 4.491 & 3659 & 815 & 2.86 & 313.68 & 153.66 & 439.03 \\
\hline 33 & 101 & 6.389 & 7861 & 1230 & 2.86 & 473.70 & 232.05 & 663.01 \\
\hline
\end{tabular}

APPENDIX - III

PTAI ( ii ) FOR WALKING DISTANCE 450 METRE

\begin{tabular}{|c|c|c|c|c|c|c|c|c|}
\hline \multirow[b]{2}{*}{$\begin{array}{l}\text { Bus } \\
\text { Stop }\end{array}$} & \multirow[b]{2}{*}{$\begin{array}{l}\text { Census } \\
\text { Ward }\end{array}$} & \multirow[b]{2}{*}{$\begin{array}{l}\text { Area } \\
\text { (Sq. } \\
\text { Km) }\end{array}$} & \multirow[b]{2}{*}{$\begin{array}{l}\text { Pop. } \\
\text { at } 2011\end{array}$} & \multirow[b]{2}{*}{$\begin{array}{l}\text { Density } \\
(\text { Persons } \\
\text { per } \mathbf{K m}^{2} \text { ) }\end{array}$} & \multicolumn{4}{|c|}{ For WalkingDistance 450 Metre } \\
\hline & & & & & $\begin{array}{l}\text { PTAI } \\
= \\
\mathbf{1} / \mathbf{0 . 4 5 0}\end{array}$ & $\begin{array}{l}\text { Pop. 450= } \\
\text { D(i) } \times 0.6364\end{array}$ & $\begin{array}{l}\text { Pop. of } \\
450-350\end{array}$ & $\begin{array}{ll}\text { D(i) } & \mathbf{x} \\
\text { PTAI }\end{array}$ \\
\hline 1 & 33 & 1.7 & 30585 & 17991 & 2.22 & 11449.58 & 4522.98 & 10051.07 \\
\hline 2 & 33 & 1.7 & 30585 & 17991 & 2.22 & 17991.18 & 11064.57 & 24587.94 \\
\hline 3 & 33 & 1.7 & 30585 & 17991 & 2.22 & 17991.18 & 11064.57 & 24587.94 \\
\hline 4 & 33 & 1.7 & 30585 & 17991 & 2.22 & 17991.18 & 11064.57 & 24587.94 \\
\hline 5 & 33 & 1.7 & 30585 & 17991 & 2.22 & 17991.18 & 11064.57 & 24587.94 \\
\hline 6 & 33 & 1.7 & 30585 & 17991 & 2.22 & 17991.18 & 11064.57 & 24587.94 \\
\hline 7 & 61 & 4.56 & 54046 & 11852 & 2.22 & 11852.19 & 7289.10 & 16198.00 \\
\hline 8 & 61 & 4.56 & 54046 & 11852 & 2.22 & 11852.19 & 7289.10 & 16198.00 \\
\hline 9 & 62 & 1.92 & 17588 & 9160 & 2.22 & 9160.42 & 5633.66 & 12519.24 \\
\hline 10 & 62 & 1.92 & 17588 & 9160 & 2.22 & 9160.42 & 5633.66 & 12519.24 \\
\hline 11 & 62 & 1.92 & 17588 & 9160 & 2.22 & 9160.42 & 5633.66 & 12519.24 \\
\hline 12 & 62 & 1.92 & 17588 & 9160 & 2.22 & 9160.42 & 5633.66 & 12519.24 \\
\hline 13 & 62 & 1.92 & 17588 & 9160 & 2.22 & 9160.42 & 5633.66 & 12519.24 \\
\hline 14 & 95 & 3.652 & 4355 & 1192 & 2.22 & 1192.50 & 733.39 & 1629.75 \\
\hline 15 & 95 & 3.652 & 4355 & 1192 & 2.22 & 1192.50 & 733.39 & 1629.75 \\
\hline 16 & 95 & 3.652 & 4355 & 1192 & 2.22 & 1192.50 & 733.39 & 1629.75 \\
\hline 17 & 95 & 3.652 & 4355 & 1192 & 2.22 & 1192.50 & 733.39 & 1629.75 \\
\hline 18 & 96 & 2.299 & 6104 & 2655 & 2.22 & 2655.07 & 1632.87 & 3628.59 \\
\hline 19 & 96 & 2.299 & 6104 & 2655 & 2.22 & 2655.07 & 1632.87 & 3628.59 \\
\hline 20 & 97 & 4.061 & 2585 & 637 & 2.22 & 636.54 & 391.47 & 869.94 \\
\hline 21 & 97 & 4.061 & 2585 & 637 & 2.22 & 636.54 & 391.47 & 869.94 \\
\hline 22 & 97 & 4.061 & 2585 & 637 & 2.22 & 636.54 & 391.47 & 869.94 \\
\hline 23 & 97 & 4.061 & 2585 & 637 & 2.22 & 636.54 & 391.47 & 869.94 \\
\hline 24 & 97 & 4.061 & 2585 & 637 & 2.22 & 636.54 & 391.47 & 869.94 \\
\hline 25 & 99 & 20.577 & 7225 & 351 & 2.22 & 351.12 & 215.94 & 479.86 \\
\hline 26 & 99 & 20.577 & 7225 & 351 & 2.22 & 351.12 & 215.94 & 479.86 \\
\hline 27 & 99 & 20.577 & 7225 & 351 & 2.22 & 351.12 & 215.94 & 479.86 \\
\hline 28 & 99 & 20.577 & 7225 & 351 & 2.22 & 351.12 & 215.94 & 479.86 \\
\hline 29 & 100 & 4.491 & 3659 & 815 & 2.22 & 814.74 & 501.07 & 1113.48 \\
\hline 30 & 100 & 4.491 & 3659 & 815 & 2.22 & 814.74 & 501.07 & 1113.48 \\
\hline 31 & 100 & 4.491 & 3659 & 815 & 2.22 & 814.74 & 501.07 & 1113.48 \\
\hline 32 & 100 & 4.491 & 3659 & 815 & 2.22 & 814.74 & 501.07 & 1113.48 \\
\hline 33 & 101 & 6.389 & 7861 & 1230 & 2.22 & 1230.40 & 756.69 & 1681.54 \\
\hline
\end{tabular}


APPENDIX - IV

POTENTIAL INDEX FOR OVERALL ATHWA DUMAS CORRIDOR

\begin{tabular}{|c|c|c|c|c|c|c|c|c|c|c|c|}
\hline \multirow[b]{2}{*}{$\begin{array}{l}\text { B } \\
\text { us } \\
\text { St } \\
\text { op }\end{array}$} & \multirow{2}{*}{$\begin{array}{l}\text { Ce } \\
\text { ns } \\
- \\
\text { us } \\
\text { W } \\
\text { ar } \\
\text { d }\end{array}$} & \multirow[b]{2}{*}{$\begin{array}{l}\text { Area } \\
\text { (Sq. } \\
\text { Km) }\end{array}$} & \multirow[b]{2}{*}{$\begin{array}{l}\text { Pop. } \\
\text { at } \\
2011\end{array}$} & \multirow{2}{*}{$\begin{array}{l}\text { Densi } \\
\text { ty } \\
\text { (Pers } \\
\text { ons } \\
\text { per } \\
\mathbf{K m}^{2} \text { ) }\end{array}$} & \multicolumn{3}{|c|}{$\begin{array}{lll}\begin{array}{l}\text { Potential } \\
\text { Diastance }\end{array} & \text { for } & \text { Walking } \\
\end{array}$} & \multirow[b]{2}{*}{$\begin{array}{l}\text { Sum Of } \\
\{\text { D(i) } \quad x \\
\text { PTAI(i)\} }\end{array}$} & \multirow[b]{2}{*}{$\begin{array}{l}\text { Average } \\
\text { of } \\
\text { adjacent } \\
\text { stops }\end{array}$} & \multirow{2}{*}{$\begin{array}{l}\text { Dist } \\
\text { ance } \\
\text { betw } \\
\text { een } \\
\text { Bus } \\
\text { Stop } \\
\text { s }\end{array}$} & \multirow[b]{2}{*}{$\begin{array}{l}\text { Potenti } \\
\text { al } \\
\text { Index }\end{array}$} \\
\hline & & & & & $\begin{array}{l}250 \\
\text { Meter }\end{array}$ & $\begin{array}{l}350 \\
\text { Meter }\end{array}$ & $\begin{array}{l}450 \\
\text { Meter }\end{array}$ & & & & \\
\hline 1 & 2 & 3 & 4 & 5 & 6 & 7 & 8 & 9 & 10 & 11 & 12 \\
\hline 1 & 33 & 1.7 & 30585 & 17991 & 14133.87 & 9694.67 & 10051.07 & 33879.61 & & & \\
\hline 2 & 33 & 1.7 & 30585 & 17991 & 14133.87 & 9694.67 & 24587.94 & 48416.48 & 41148.05 & 339 & 121.38 \\
\hline 3 & 33 & 1.7 & 30585 & 17991 & 14133.87 & 9694.67 & 24587.94 & 48416.48 & 48416.48 & 491 & 98.61 \\
\hline 4 & 33 & 1.7 & 30585 & 17991 & 14133.87 & 9694.67 & 24587.94 & 48416.48 & 48416.48 & 379 & 127.75 \\
\hline 5 & 33 & 1.7 & 30585 & 17991 & 14133.87 & 9694.67 & 24587.94 & 48416.48 & 48416.48 & 276 & 175.42 \\
\hline 6 & 33 & 1.7 & 30585 & 17991 & 14133.87 & 9694.67 & 24587.94 & 48416.48 & 48416.48 & 395 & 122.57 \\
\hline 7 & 61 & 4.56 & 54046 & 11852 & 9311.08 & 6386.64 & 16198.00 & 31895.72 & 40156.10 & 491 & 81.78 \\
\hline 8 & 61 & 4.56 & 54046 & 11852 & 9311.08 & 6386.64 & 16198.00 & 31895.72 & 31895.72 & 548 & 58.20 \\
\hline 9 & 62 & 1.92 & 17588 & 9160 & 7196.42 & 4936.16 & 12519.24 & 24651.82 & 28273.77 & 647 & 43.70 \\
\hline 10 & 62 & 1.92 & 17588 & 9160 & 7196.42 & 4936.16 & 12519.24 & 24651.82 & 24651.82 & 589 & 41.85 \\
\hline 11 & 62 & 1.92 & 17588 & 9160 & 7196.42 & 4936.16 & 12519.24 & 24651.82 & 24651.82 & 389 & 63.37 \\
\hline 12 & 62 & 1.92 & 17588 & 9160 & 7196.42 & 4936.16 & 12519.24 & 24651.82 & 24651.82 & 271 & 90.97 \\
\hline 13 & 62 & 1.92 & 17588 & 9160 & 7196.42 & 4936.16 & 12519.24 & 24651.82 & 24651.82 & 501 & 49.21 \\
\hline 14 & 95 & 3.652 & 4355 & 1192 & 936.83 & 642.59 & 1629.75 & 3209.16 & 13930.49 & 293 & 47.54 \\
\hline 15 & 95 & 3.652 & 4355 & 1192 & 936.83 & 642.59 & 1629.75 & 3209.16 & 3209.16 & 501 & 6.41 \\
\hline 16 & 95 & 3.652 & 4355 & 1192 & 936.83 & 642.59 & 1629.75 & 3209.16 & 3209.16 & 618 & 5.19 \\
\hline 17 & 95 & 3.652 & 4355 & 1192 & 936.83 & 642.59 & 1629.75 & 3209.16 & 3209.16 & 316 & 10.16 \\
\hline 18 & 96 & 2.299 & 6104 & 2655 & 2085.82 & 1430.70 & 3628.59 & 7145.12 & 5177.14 & 766 & 6.76 \\
\hline 19 & 96 & 2.299 & 6104 & 2655 & 2085.82 & 1430.70 & 3628.59 & 7145.12 & 7145.12 & 337 & 21.20 \\
\hline 20 & 97 & 4.061 & 2585 & 637 & 500.07 & 343.01 & 869.94 & 1713.02 & 4429.07 & 892 & 4.97 \\
\hline 21 & 97 & 4.061 & 2585 & 637 & 500.07 & 343.01 & 869.94 & 1713.02 & 1713.02 & 399 & 4.29 \\
\hline 22 & 97 & 4.061 & 2585 & 637 & 500.07 & 343.01 & 869.94 & 1713.02 & 1713.02 & 194 & 8.83 \\
\hline 23 & 97 & 4.061 & 2585 & 637 & 500.07 & 343.01 & 869.94 & 1713.02 & 1713.02 & 193 & 8.88 \\
\hline 24 & 97 & 4.061 & 2585 & 637 & 500.07 & 343.01 & 869.94 & 1713.02 & 1713.02 & 176 & 9.73 \\
\hline 25 & 99 & 20.577 & 7225 & 351 & 275.84 & 189.20 & 479.86 & 944.91 & 1328.96 & 1193 & 1.11 \\
\hline 26 & 99 & 20.577 & 7225 & 351 & 275.84 & 189.20 & 479.86 & 944.91 & 944.91 & 301 & 3.14 \\
\hline 27 & 99 & 20.577 & 7225 & 351 & 275.84 & 189.20 & 479.86 & 944.91 & 944.91 & 664 & 1.42 \\
\hline 28 & 99 & 20.577 & 7225 & 351 & 275.84 & 189.20 & 479.86 & 944.91 & 944.91 & 656 & 1.44 \\
\hline 29 & 100 & 4.491 & 3659 & 815 & 640.06 & 439.03 & 1113.48 & 2192.57 & 1568.74 & 642 & 2.44 \\
\hline 30 & 100 & 4.491 & 3659 & 815 & 640.06 & 439.03 & 1113.48 & 2192.57 & 2192.57 & 346 & 6.34 \\
\hline 31 & 100 & 4.491 & 3659 & 815 & 640.06 & 439.03 & 1113.48 & 2192.57 & 2192.57 & 419 & 5.23 \\
\hline 32 & 100 & 4.491 & 3659 & 815 & 640.06 & 439.03 & 1113.48 & 2192.57 & 2192.57 & 636 & 3.45 \\
\hline 33 & 101 & 6.389 & 7861 & 1230 & 966.60 & 663.01 & 1681.54 & 3311.15 & 2751.86 & 1613 & 1.71 \\
\hline
\end{tabular}

Overall Potential Index $=\mathbf{7 4 . 9 8}$ per $\mathrm{km}$ 